\title{
外陰部 Paget 病と重複癌
}

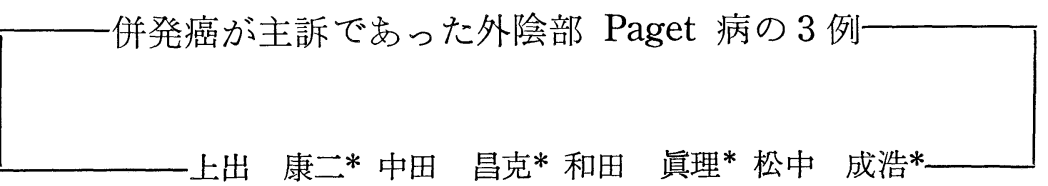

\section{Summary}

併発癌が主訴であった外陰部 Paget 病の 3 例を報告した。症例 1 ，75歳男性, 悪性リン 八腫併発例。症例 2,78 歳男性, 前立腺癌併発例。症例 3,61 歳女性, 乳癌先行例。乳房 外 Paget 病に和ける重複癌発生頻度は, 自験例も含め $16.1 \%$ 。下部消化器系, 泌尿生殖系 の癌 $(50 \%)$, 腺癌 (60\%), 同時併発例 $(50 \%)$ ) が多く, 重複癌後発症例で予後不良（腫 癔死， $43.8 \%$ ）の特徴を有した。その発生原因として, 共通の発癌物質による外陰部皮㲊 の污染, 共通の発癌分泌因子, 微小表皮内転移などを推定した。

\section{緒言}

従来よりPaget病を発症する個体にはsystemic cancer proneness を有し, systemic cancer の検 索が必要であることがいわれている。われわれ も主訴が他臓器ないし他部位の悪性腫瘍と診断 を受けた症例で長期間外陰部に Paget 病を併発 していた 3 例を最近相次いで経験したので報告 する。あわせて乳房外 Paget 病に扣ける重複癌 に関し, 定義, 重複癌の種類と特徵, 発生頻 度, 発症機序について考察する。

\section{症例}

症例 $1: 75$ 歳, 男性

初 診：昭和 61 年 7 月 25 日

既往歴：59歳時十二指腸潰瘍

* Koji UEDE, Masakatsu NAKATA, Mari WADA, Masahiro MATSUNAKA: 和歌山県 立医科大学皮膚科学教室
家族歴：特記事項なし。

現病歴：1 力月来右上腕伸側に急速に増大す る腫瘤を訴兄来院。入院後, 全身の皮膚の精査 で陰茎背側に軽度櫁痒を伴う紅色局面を見出し た。患者によると昭和 60 年 9 月ごろ気づき市販 の外用薬のみ塗布し医治は受けていなかった。

現 症：(1)右上腕伸側； $10 \times 6 \mathrm{~cm}$ 大の下床 之可動性のない弾性硬の皮下腫瘤を認める。(2) 㓌茎背側；直径 $4 \mathrm{~cm}$ 大の落屑性紅色局面を認 める。腋窩, 鼠径リンパ節は触知せず。

一般検査所見: 軽度の貧血, $\mathrm{s}-\mathrm{AC} 52 \mathrm{mg} / \mathrm{d} l$, IAP $431 \mathrm{mcg} / \mathrm{ml}$, ferritin $180 \mathrm{ng} / \mathrm{ml}$, PHA 3, $079 \mathrm{cpm}$, control 1,460, Con A 5, $466 \mathrm{cpm}$, control 1,460, OKT $362.5 \%$, OKT 455.6 $\%$, OKT $815.5 \%, \quad$ OKT $4 /$ OKT 8 3.7, OKIA $114.6 \%$, Leu $718.0 \%$, NK 活性 $9.5 \%$ ，血清 CEA， $\alpha$-FP は検査せず。

病理組織学的所見：(1)右上腕病巣（初診時） （図 1）；Grenz zone を介し真皮上層から少な くとも皮下脂肪織まで, 円型あるいは軽度convolute した核を有す，細胞質の豊富ないわゆる 


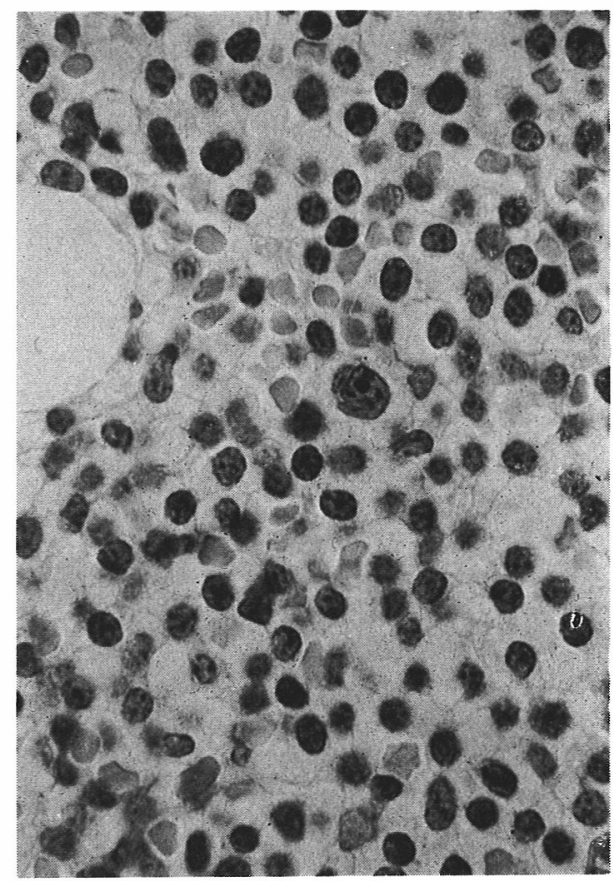

図 1. 症例 1。右上腕伸側の初診時組織所見 円型むるいは俥度 convolute した核を 有し，細胞質の豊富な腫瘍細胞が浸 潤。中にはきれこみのある巨大核を有 す細胞 女混在。non-Hodgkin's lymphoma, large cell type

clear cell を主体とした 腫瘍細胞が 浸潤。中に は切れこみのある巨大核を有す細胞も混在。核 分裂像も多数認める。異型細胞の表皮向性は認 めない。病理組織学的診断は, non-Hodgkin's lymphoma, large cell type で，浸潤腫瘍細胞は $\mathrm{CD}^{+}{ }^{+} \mathrm{CD}^{+}{ }^{+} \mathrm{CD}^{-}{ }^{-} \mathrm{CD} 20^{-}$HLA-DR ${ }^{-}$helper/ inducer T-cell lymphoma と考光られた。(2)陰 茎病巣（図 2); 表皮内には胞体が淡明で大型 のあるいは角化細胞と同大の Paget 細胞が混在 し，表皮内に散在性にあるいは胞巣を形成して 認め，一部基底膜を破壊し真皮内一浸潤すると ころもみられる。

治療および経過（図3）：入院当初，全身の 精査で転移巣は認めなかった。悪性りンパ腫に 対し CHOP 療法 2 クール，コバルト照射療法 を, Paget 病巣に natural $\beta$-IFN (フェロン, 東レ)の局注を試みた。しかし悪性リンパ腫病

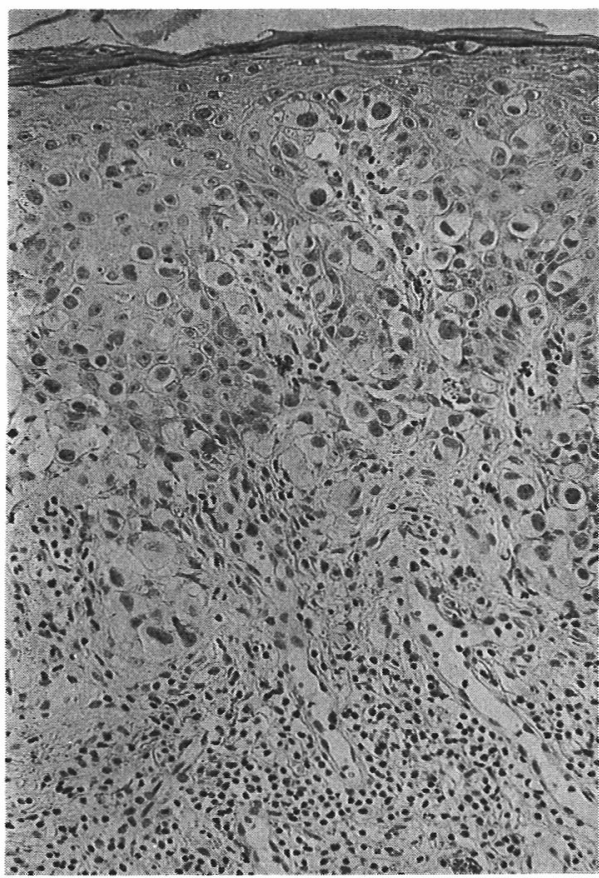

図 2. 症例 1 。外陰部組織所見

胞体の明るい Paget 細胞が表皮内に散在性 に認める。一部真皮内へも浸潤

変は引き続き急速に拡大, 肺転移, 呼吸不全に より入院後約 2 カ月で死亡した。

症例 $2: 78$ 歳, 男性

初 診：昭和 61 年 12 月 4 日

既往歴：68歳時腎孟炎

家族歴：特記事項なし。

現病歴：3 力月前より食欲不振, 排尿困難, 血清 PAP の高値により当院泌尿器科紹介され 精查の結果, 右第一胁骨転移を伴う前立腺癌の 診断を受ける。この際泌尿器科主治医に外陰部 の皮疹を指摘され当科紹介された。患者による と， 2 年前ごろ陰茎基部陰囊に初発し徐々に拡 大。地元皮膚科を 3 力所受診, 加療されるも軽 快しないまま放置していた。

現 症：(1)外陰部; 院雴, 陰茥基部, 恥骨部 飞褐色斑を伴う $8.5 \mathrm{~cm} \times 4 \mathrm{~cm}$ 大の苔癖化局面 を認める。両側鼠径リンパ節は触知せず。(2)膀 胱鏡所見; 膀胱頸部より後部尿道にかけ浸潤性 の腫瘤を認めとくに前立腺部尿道ではほとんど 


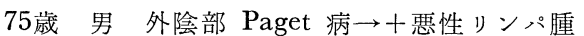

Large cell type NHL

Helper T-cell Lymphoma

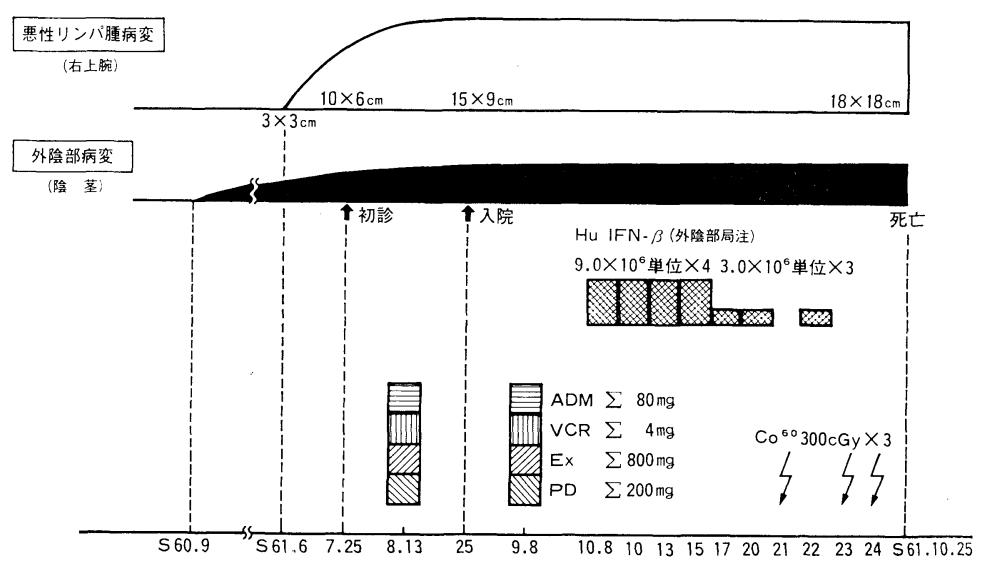

図 3. 症例 1 。治療拈よび経過

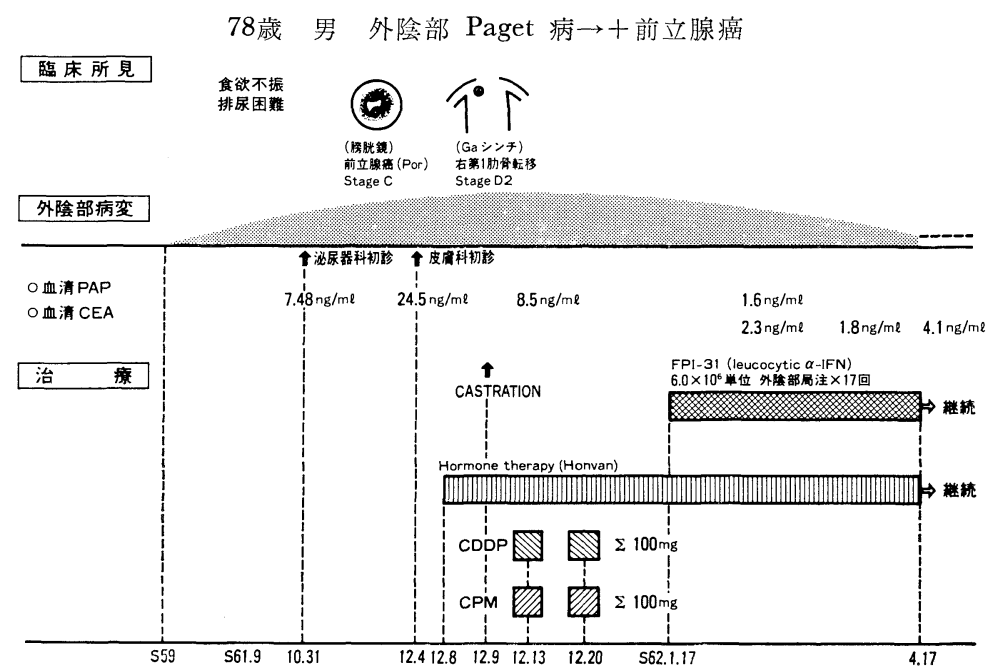

図 4. 症例 2 。治療および経過

全周性に腫瘍の浸潤を認める。

一般検查所見 : 軽度貧血, 血清 CEA $2.3 \mathrm{ng}$ / $\mathrm{m} l, \alpha$-FP $3.3 \mathrm{ng} / \mathrm{m} l$, s-AC $68 \mathrm{mg} / \mathrm{d} l$, IAP 507 $\mathrm{mcg} / \mathrm{ml}$, PAP $24.5 \mathrm{ng} / \mathrm{m} l$, PHA 21, 082, control 100, OKT 3 67.6\%, OKT $444.1 \%$, OKT 8 $21.0 \%$, OKT $4 /$ OKT 82.10 , OKIA 12.7 $\%$, Leu $720.9 \%$, NK 活性 $22 \%$ 。

病理組織学的所見 (初診時): (1) 前立腺 (針 生検); poorly differentiated adenocarcinoma clear cell type。(2)外陰部病巣; 胞体の明るい 大型の Paget 細胞を蜂巣状に認める。同細胞は 表皮内, 毛包内に限局し, 汗器官や間質への明 らかな浸潤を認めず。 Paget 細胞は一部 alcian blue $(+)$, 大部分ジアスターゼ抵抗性 PAS $(+)$, $\operatorname{CEA}(+)$ 。

治療および経過（図 4)：前立腺癌；(1) 除辠 術, CDDP, CPM, ホルモン療法により血清 PAP 值の低下を認めたため，ホルモン療法の 
60歳 女 左乳癌 $\rightarrow$ 外院部 Paget 病

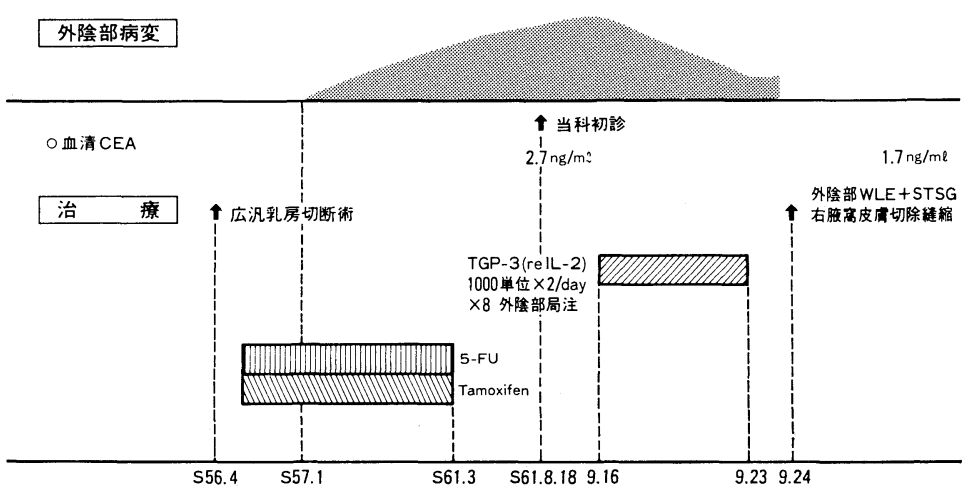

図 5. 症例 3. 治療打よび経過

み継続中。現在膀脱鏡にても前立腺癌病変は縮 小。(2)外陰部 Paget 病; natural $\alpha$-IFN (FPI31, 扶桑) の局注により病巣は縮小（奏効度, $\mathrm{PR}$ )，患者の希望もあり手術を行わず局注を継 続。昭和62年 8 月健在。

症 例 3:61歳, 女性

初 診: 昭和 61 年 8 月 18 日

既往歴：昭和 56 年 4 月, 左乳癌のため広沉乳 房切断術を受け, 術後 5-FU, tamoxifen の内 服を 続けるが 再発を認めないため昭和 61 年 3 月で内服中止する。 59 歳時肝血管腫。糖尿病 $(+)$ 。

家族歴 : 父, 胃癌。母, 胆囊癌。姉, 糖尿病。

現病歴：昭和 57 年 1 月ころより外陰部の接触 痛特よび発赤に気づいたため近医拉よび皮膚科 を計 4 力所受診。いずれも外用療法のみ指示さ れ，延べ 3 年間外用を続けるも病変は拡大。子 宮癌の定期検診のため当院分院婦人科を受診し たときに外陰部病変を指摘され，当科紹介を受 け来院した。

現 症 : 左大陰唇から会陰部, 肛囲にかけ境 界不明瞭な菲薄化した紅色調変化を認める。両 側鼠径リンパ節は触知せず。

一般検查所見: 一般検血, 肝機能, 腎機能飞 異常なし。FBS $138 \mathrm{mg} / \mathrm{d} l$, 血清 CEA $2.7 \mathrm{ng} /$ $\mathrm{m} l, \alpha$-FP $3.3 \mathrm{ng} / \mathrm{ml}$, s-AC $48 \mathrm{mg} / \mathrm{d} l$, IAP 356 $\mathrm{mcg} / \mathrm{ml}$, OKT $370.1 \%$, OKT $436.2 \%$,
OKT $836.0 \%$, OKT 4/OKT 8 1.01, OKIA 1 $23.9 \%$, Leu $732.3 \%$, NK 活性 $16 \%$, ADCC 活性 $44 \%$ 。

病理組織学的所見：(1)左乳房切除標本; welldifferentiated ductal carcinoma。(2)外陰部病巣 (初診時); 胞体の明るい大型の Paget 細胞が表 皮内散在性にあるいは基底膜直上に列をなして 存在する。一部毛包内にも散在性に認めるが汗 器官や真皮への 浸潤はみられない。Paget 細胞 は alcian blue $(+)$, ジアスターゼ抵抗性 PAS $(+), \operatorname{CEA}(+)$ 。

治療および経過（図 5)：recombinant IL-2 (TGP-3, 武田) 局注後, 外陰部病巣広沉切除 と分層植皮術施行。同時飞右腋窩部皮膚を切除 （左腋窩皮膚は乳癌手術時に切除されている）。 昭和63年 3 月健在。

\section{考按}

\section{1）重複癌の定義1)}

重複癌とは一般に，(1)各腫瘍は一定の悪性像 を示す，(2)各腫瘍は互いに離れた部位を占め る，(3)一方の腫瘍が他の腫瘍の転移であること が除外されなければならない，と定義される。 この条件を満足するためには, 他癌との連続性 扣よび転移を詳細な肉眼的, 組織学的検索によ り否定するか, 組織学的, 組織化学的, 免疫組 
表 1. 乳房外 Paget 病と重複癌症例 (本邦報告例・自験例を含む)。 50 例中 2 例は三重複癌のため計 52 例となる。

\begin{tabular}{|c|c|c|c|c|}
\hline & $\begin{array}{l}\text { 乳房外 } \\
\text { Paget 病 }\end{array}$ & $\begin{array}{l}\text { Paget } \\
\text { 病先行 }\end{array}$ & 同時併発 & 重複癌先行 \\
\hline 直 腸 癌 & 7 & $2(1)$ & 5 & 0 \\
\hline 胃癌 & 6 & $3(2)$ & 2 & 1 \\
\hline 前立腺 癌 & 6 & 2 & 3 & 1 \\
\hline 膀 胱 癌 & 6 & 1 & 1 & $4(1)$ \\
\hline 肝 臓 癌 & 4 & 1 (1) & 3 & 0 \\
\hline 結 腸 癌 & 4 & 2 & 2 & 0 \\
\hline 乳癌 & 3 & 0 & 1 (1) & 2 \\
\hline 悪性リンパ腫 & 2 & 0 & $2(1)$ & 0 \\
\hline 子 宮 澒 癌 & 2 & 0 & 2 & 0 \\
\hline 肛 門 癌 & 2 & 1 (1) & 0 & 1 \\
\hline 食道 癌 & 1 & $1(1)$ & 0 & 0 \\
\hline 肺癌 & 1 & 1 & 0 & 0 \\
\hline 腎 孟 癌 & 1 & 0 & 0 & 1 \\
\hline 舌癌 & 1 & 1 & 0 & 0 \\
\hline 膵 癌 & 1 & 0 & 1 & 0 \\
\hline 睪丸肉腫 & 1 & 0 & 0 & 1 \\
\hline 有棘細胞癌 & 2 & 1 (1) & 1 & 0 \\
\hline 基底細胞癌 & 2 & 0 & 2 & 0 \\
\hline 計 & 52 & $16(7)$ & 25 (2) & 11 (1) \\
\hline
\end{tabular}

織学的に両癌が全く別個のものであることを証 明しなければならない。乳房外 Paget 病の場合 これが困難な場合も少なくない。つまり近傍臓 器癌から外陰部に連続性波及（経尿道, 経直 腸，経胵的）した場合，あるいは転移性皮膚癌 が epidermotropic carcinoma の所見を呈した 場合に一見 Paget 病様外観を示すからである。 自験例では症例 2 が問題となるであろらが，亀 頭部には肉眼的, 組織学的に異常はみられず, また外陰部の組織に転移巣を疑う所見がみつか らなかったことから一応否定的であるが，いず れも生検組織で検討しているため完全に否定さ れたわけではない。前立腺癌特異的腫瘍マーカ

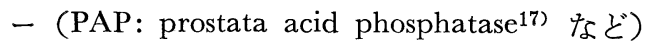
あるいは逆にアポクリン腺由来腫瘍に特異的と 思われる腫瘍マーカー（GCDFP： gross cystic disease fluid protein ${ }^{18)}$ など）による免疫組織 学的に, あるいは細胞内シアル酸の組織化学的
分析 ${ }^{14) 199}$ などにより両癌を比較検討する必要が あると思われる。

\section{2 ）重複癌の種類と特徵（表 1)}

文献上乳房外 Paget 病に扮ける重複癌の本邦 報告例 ${ }^{22}$ 16) は 50 例を数兄る。その特徵は林原 $ら^{2)}$ も指摘するように Paget 病巣近傍の下部消 化器, 泌尿生殖系の癌が26例で半数を占め, 組 織別では腺癌が30例で圧倒的に多い。重複癌合 併時期は，同時併発例が 25 例 (50\%), 重複癌 後発例16例 $(32 \%)$, 重複癌先行例11例 $(22 \%)$ で同時併発症例を半数隹認める。重複癌合併時 期と腫瘍死との関係についてみると, 重複癌後 発例 $43.8 \%$, 先行例 $9 \%$, 同時併発例 $8 \%$ に 腫瘍死を認め, 当然ながら重複癌後発症例は圧 倒的に予後不良である。

\section{3）重複癌発生頻度}

乳房外 Paget 病に抢ける重複癌発生頻度につ いて池田ら ${ }^{2)}$ によれば 62 例中 11 例 $(17.7 \%)$ ， 
石原 ${ }^{11)}$ とよれば28例中 4 例 $(14.3 \%)$ に重複癌 がみられたと報告している。自験例では22例中 3 例 (13.6\%) であった。全癌に括ける重複癌 発生頻度は $5 \%$ 前後の報告1)がなされている。 これと比較すれば乳房外 Paget 病（とくに外陰 部・肚囲 Paget 病）は明らかに重複癌発生頻度 は高く, 皮膚癌中ではボーエン病と同程度に発 生するものと思われる。

\section{4 ）重複癌発生機序}

同時性重複癌では異時性重複癌と異なり先行 重複癌治療時の化学療法や放射線療法による二 次癌誘発を考慮しなくてよい。乳房外 Paget 病 についていえば，重複癌の高頻度発生，同時併 発癌や Paget 病巣近傍の消化器系や泌尿生殖 系（つまり外陰部と直接連続する藏器）の重複 癌特よび腺癌を多数認めるなどの種々の特徴か ら偶然に発生するとは考光がたい。これらの特 徵より, 消化器系, 泌尿生殖系から, それらを 癌化せしめる発癌物質の排泄による外陰部皮膚 の污染, 共通の発癌分泌因子による腺癌誘発, 近傍藏器からの微小な表皮内転移，税田 ${ }^{20)}$ が 指摘するように性ホルモン不均衡による前立腺 癌, 乳癌, 子宮癌などの性ホルモン依存性臟器 癌の誘発，自験例に扮ける癌家族歴にみられる ような内因的素因などの可能性を考旮たい。乳 房外 Paget 病に打怕重複癌発生は Paget 病発 症機序を研究するら壳でも興味あるものと思わ れる。

最後に, 自験例でもみられるように外陰部 Paget 病の場合，患者はもとより皮膚科医でさ 光も股部白癬あるいは皮膚炎として軽くみなさ
れ，誤った治療を長期間続ける症例が非常に多 い。いうまでもなく外陰部の難治性皮膚炎様病 変は必らず生検し, 乳房外 Paget 病と診断がつ いた場合, 重複癌の高頻度発生, 重複癌後発症 例は予後不良であるといら事実から，定期的に 全身検査, とくに下部消化器系, 泌尿生殖系の 精查を，少なくとも血清 CEA， $\alpha$-FP，PAP の 検査を行い，重複癌の早期発見に努めることの 重要性を痛感した。

\section{文献}

1）関根 毅：最新医学，40：1580-1587, 1985.

2）林原義明, 他：医薬の門，25：69-74，1985.

3）田代正昭：西日皮膚，37：296，1975.

4）妙中俊文, 他：日臨外会誌，43：139，1982.

5）三好 紀，他：日皮会誌，92：360，1982.

6）村田英俊，他：日皮会誌，94：1174，1984.

7）臀矢信弘，他：日皮会誌，94：1417，1984.

8）森 義顕, 他：癌治, 19: 97, 1984.

9）小泉雄一郎：日皮会誌，94：761，1984.

10）舟本 寛，他：産科と婦人科，51：106-110, 1984.

11) 石原和之：最新医学，40：1675-1685, 1985.

12）太田有史，他：日皮会誌，95：1102，1985。

13）平野 節，他：日皮会誌，96: 769， 1986.

14）畑野武嗣, 他：西日皮㲊，48：769，1986.

15）増田哲夫, 他：日皮会誌, 96: 954, 1986.

16）福谷恵子, 他：日泌尿会誌, 77：1668，1986.

17) Jöbsis, A.C., et al.: Histochem. J., 13: 961973, 1981.

18) Mazoujian, G., et al.: Am. J. Surg. Pathol., 8: 43-50, 1984.

19）笹井陽一郎，他：西日皮膚，43：1193-1198, 1981.

20）税田武三，他：西日皮膚，40：292，1978. 